\title{
Experimental and Numerical Investigation of Load-Settlement Behaviour to Model Shallow Foundation rest on Sandy Soil
}

\author{
Bayram ATEŞ ${ }^{1 *}$, Erol ŞADOĞLU ${ }^{2}$ \\ ${ }^{1}$ Dr., Republic of Turkey Social Security Institution, Trabzon Provincial Directorate, 61040, Trabzon, Turkey, \\ ${ }^{2}$ Associate Professor, Department of Civil Engineering, Karadeniz Technical University, 61080, Trabzon, \\ Turkey,
}

Geliş / Received: 16/01/2021, Kabul / Accepted: 15/04/2021

\begin{abstract}
Improvement of technology gives the change to humankind to build larger, heavier and more complex structures. For geotechnical engineers, faced with transferring the loads that is more complex and increasing, determination of the load-settlement behaviour has become inevitable for the reliable foundation design. In this study, it is aimed to determinate the bearing and load-settlement behavior of the shallow foundations. For this purpose, a test setup has been formed and loading tests have been carried out by means of small scale model foundation rest on the granular soil with the different relative densities situations. Additionally, numerical analyses, adhering to the experimental program for $1 \mathrm{~g}$ physical model tests, have been carried out with finite element based software ABAQUS/CAE and the obtained results have been compared with the experimental results. As a result of the study it is shown that the relative density is a very effective parameter for the load-settlement behavior of the shallow foundations. The results can serve as a reference for the preliminary assessment of bearing and load-settlement behavior of shallow foundation in sandy soils without conducting expensive and time-consuming field trials.
\end{abstract}

Keywords: Shallow foundation, $1 \mathrm{~g}$ physical model test, numerical analysis, load-settlement behavior

\author{
Kum Zemine Oturan Model Yüzeysel Temelin Yük-Oturma Davranışının Deneysel ve Nümerik Olarak \\ İncelenmesi
}

Öz

Teknolojinin gelişmesi insanoğluna daha geniş, daha ağır ve daha karmaşık yapılar inşa etme firsatı vermiştir. Artan ve karmaşık hale gelen yükleri zemine aktarma problemi ile yüzleşen geoteknik mühendisleri için temellerin yük-oturma davranışını anlamak güvenli temel tasarımı için kaçınılmaz hale gelmiştir. Bu çalışmada yüzeysel temellerin yük-oturma ve taşıma davranışının belirlenmesi amaçlanmıştır. Bu amaçla bir deney düzeneği oluşturulmuş ve farklı rölatif sıkılıklara sahip granüler zemine oturan küçük ölçekli model temeller ile yükleme deneyleri gerçekleştirilmiştir. Ayrıca; fiziksel model testler için deney programına bağlı kalarak sonlu elemanlar yöntemine dayanan ABAQUS/CAE programı ile sayısal analizler yapıllmış, elde edilen sonuçların deney sonuçları ile olan uyumu araştırılmıştır. Yapılan çalışmalar sonucunda rölatif sıkılığın, yüzeysel temellerin yük-oturma davranışı üzerinde etkili bir parametre olduğu görülmüştür. Sonuçlar maliyetli ve zaman alıcı saha deneyleri yapmadan kumlu zemine oturan yüzeysel temellerin taşıma ve yükoturma davranışlarının ön değerlendirmesi için bir referans görevi görebilir.

Anahtar Kelimeler: Yüzeysel temel, $1 \mathrm{~g}$ fiziksel model deney, nümerik analiz, yük-oturma davranışı

*Corresponding Author: bayramates61@ hotmail.com 


\section{Introduction}

Shallow foundations are one of the most common types of foundations for buildings, retaining walls and other structures. These foundations are the inexpensive foundation solution compared with other types of foundation, deep foundations such as the piles and caissons. The two key properties required in the design of the shallow foundations are the bearing capacity (i.e., qu) and settlement (i.e., $\delta$ ) behavior of soils. Structures such as silos, antenna towers, bridges, power plants, retaining walls and house subdivisions can be constructed on shallow foundations in the sandy soils. The shallow footings are typically designed to transfer the loads safely from the superstructure to the supporting soil such that the settlements are in acceptable limits as per the design and construction codes. The bearing capacity of the shallow foundations is conventionally estimated using the approaches originally presented by Terzaghi and Meyerhof assuming the soil is in a state of saturated condition (Terzaghi 1943; Meyerhof 1951). A framework for interpreting the bearing capacity and settlement behavior from the experimental and the modeling studies for the unsaturated sands is recently evolving (Vanapalli and Mohamed 2007; Oh and Vanapalli 2011; Hosseini 2014; Hossein, Nazir and Ehsan 2016). In addition; several researchers carried out investigations to study the bearing capacity of the unsaturated soils (Broms 1963; Oloo, Fredlund and Gan 1997; Costa, Cintra and Zornberg 2003; Mohamed and Vanapalli 2006; Krabbenhoft, Clausen and Damkilde 2012; Vanapalli and Mohamed 2013;).

Unlike the structures, the soil shows heterogeneous features, variations in stiffness, and energy dissipation according to the stress conditions, as well as nonlinear strain behavior. As it is difficult to accurately reflect these characteristics, a reliable assessment of the complicated behavior and interactions among soil, foundations, and structures requires not only numerical modeling but also experimental verification through physical modeling. Although there are theoretical studies in the literature on this subject, model experiments are very few. The load-settlement behavior of the shallow foundation is not very well understood. Therefore, the main goal of this study is investigating load-settlement and bearing behavior of the shallow foundations resting on non-cohesive soil.

\section{Material and Method}

\subsection{Experimental Study}

Investigation of the raft foundation with the field tests is required a high cost. Therefore, the studies on the load-settlement behavior of raft foundation can be performed with the smallscale model tests. In this study; an experiment setup was made in order to observe the loadsettlement of the vertical loaded raft foundations in the granular soil. The main parts of the experimental setup consist of a test tank, model raft, a loading apparatus, Linear Variable Differential Transformers (LVDT's), a load cell, a sand surface leveling tool and sand. A gear driven loading press of a triaxial test device was used as the loading apparatus. In addition, a compaction device was used to compact the sand in some tests. A digital camera and a computer were used to record data during tests. The tests were carried out in the Geotechnical Laboratory of Karadeniz Technical University. 


\subsubsection{Test Tank}

The inside of the test tank is a cube prism with a length of $1.00 \mathrm{~m}$, a width of $1.00 \mathrm{~m}$ and a height of $1.00 \mathrm{~m}$. The tank sizes were selected by considering similar studies and the results of the numerical analysis so that no boundary effect occurs (Cao, Wong and Chang 2004; Mendonça and Paiva 2000; Vanapalli and Mohamed 2007; Krabbenhoft, Clausen and Damkilde 2012; Vanapalli and Mohamed 2013; Hossein, Nazir and Momeni 2016). The frame of the tank was made of steel profiles. The steel braces were welded at certain points around the tank and supported by bolts to ensure rigidity of the tank. The horizontal lines with $50 \mathrm{~mm}$ intervals were drawn inner surfaces of the tank to place the sand homogeneously and to obtain desired relative density of the sand easily. The movements of both the tank and the sand surface were observed with the help of dial gauges in order to control the boundary effect during loading. In addition, a steel beam was mounted to the test tank to connect the loading apparatus (Fig. 1).

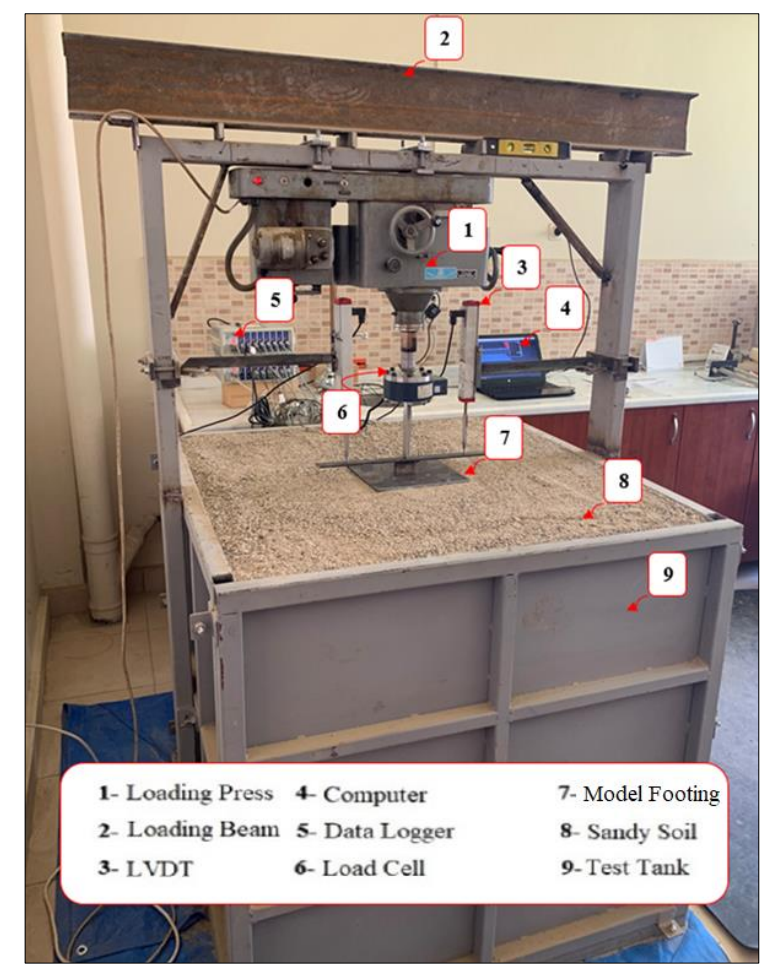

Fig.1 A view of experimental setup

\subsubsection{Model Footing}

Literature survey and preliminary tests were performed to determine dimensions of the model raft foundation used in the laboratory tests. The length, width and thickness of the model footing were determined as $160 \mathrm{~mm}, 160 \mathrm{~mm}$ and $6 \mathrm{~mm}$, respectively. (Cao, Wong and Chang 2004; Mendonça and Paiva 2000; Vanapalli and Mohamed 2007; Vanapalli and Mohamed 2013). A thick abrasive paper is adhered to the base of the model raft foundation in accordance with friction and practical conditions (Fig. 2). 


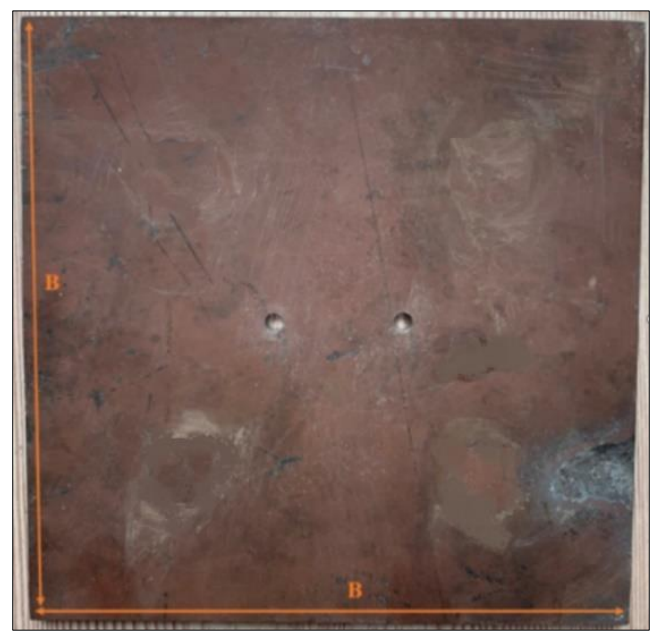

Fig.2. The model raft foundation $(B=160 \mathrm{~mm})$

\subsubsection{Sand}

The sand, taken from the east coast of Black sea adjacent to Iyidere district (Rize), was used in the test (Fig. 3).

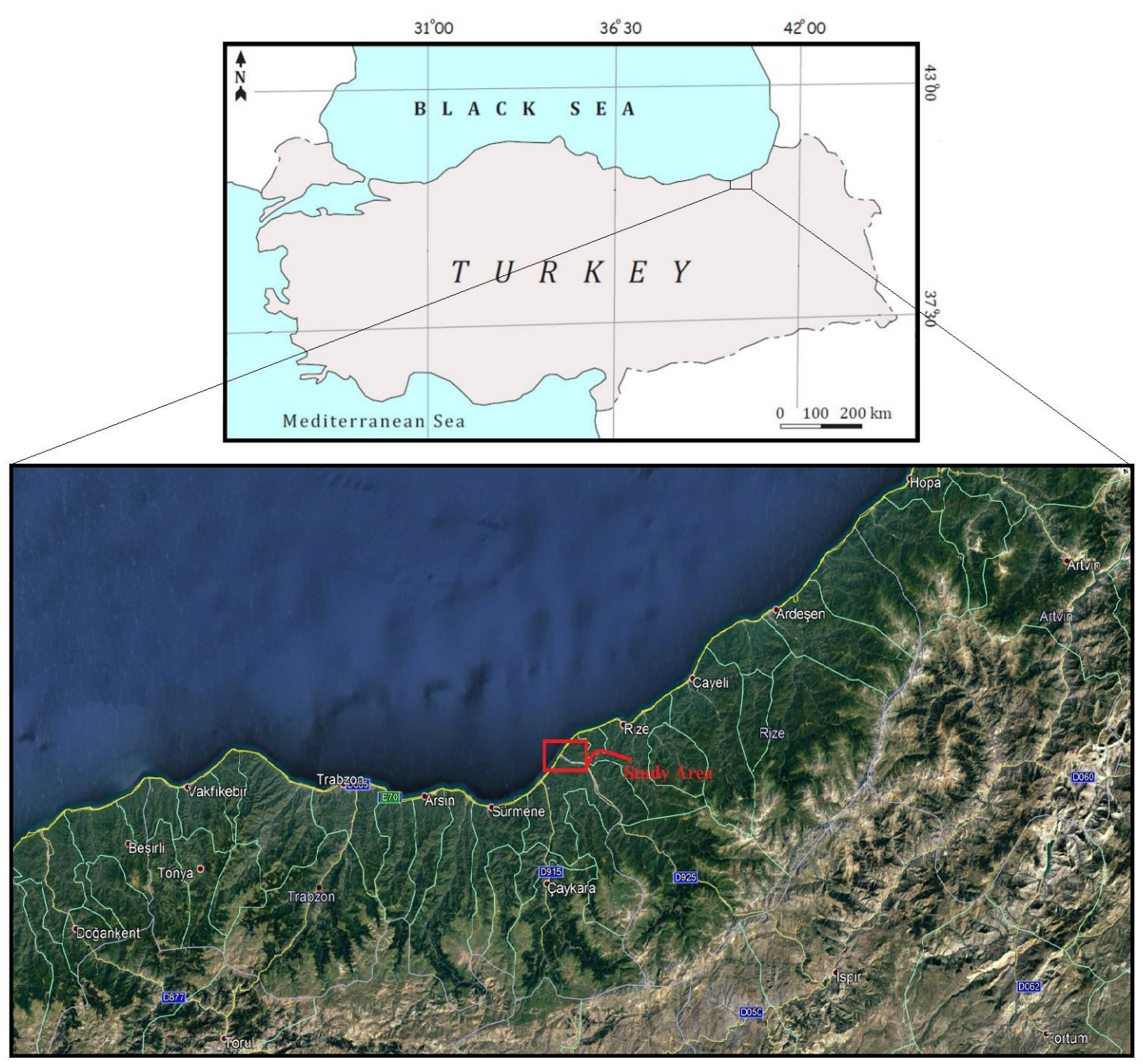

Fig.3 Location map of the sand for this study 
Grain size distribution of the sand was determined according to ASTM D-6913 (2017). $\mathrm{D}_{10}=0.28 \mathrm{~mm}$ (effective diameter), $\mathrm{D}_{30}=0.73 \mathrm{~mm}$ and $\mathrm{D}_{60}=1.71 \mathrm{~mm}$ were determined from grain size distribution of the sand. In addition, uniformity coefficient and curvature coefficient were calculated as $C_{u}=6.11$ and $C_{c}=1.1$, respectively. The grain diameter of the sand is between 0.1-5.0 mm (coarse-medium) and it is classified as well graded sand (SW) according to the Unified Soil Classification System (Fig. 4).

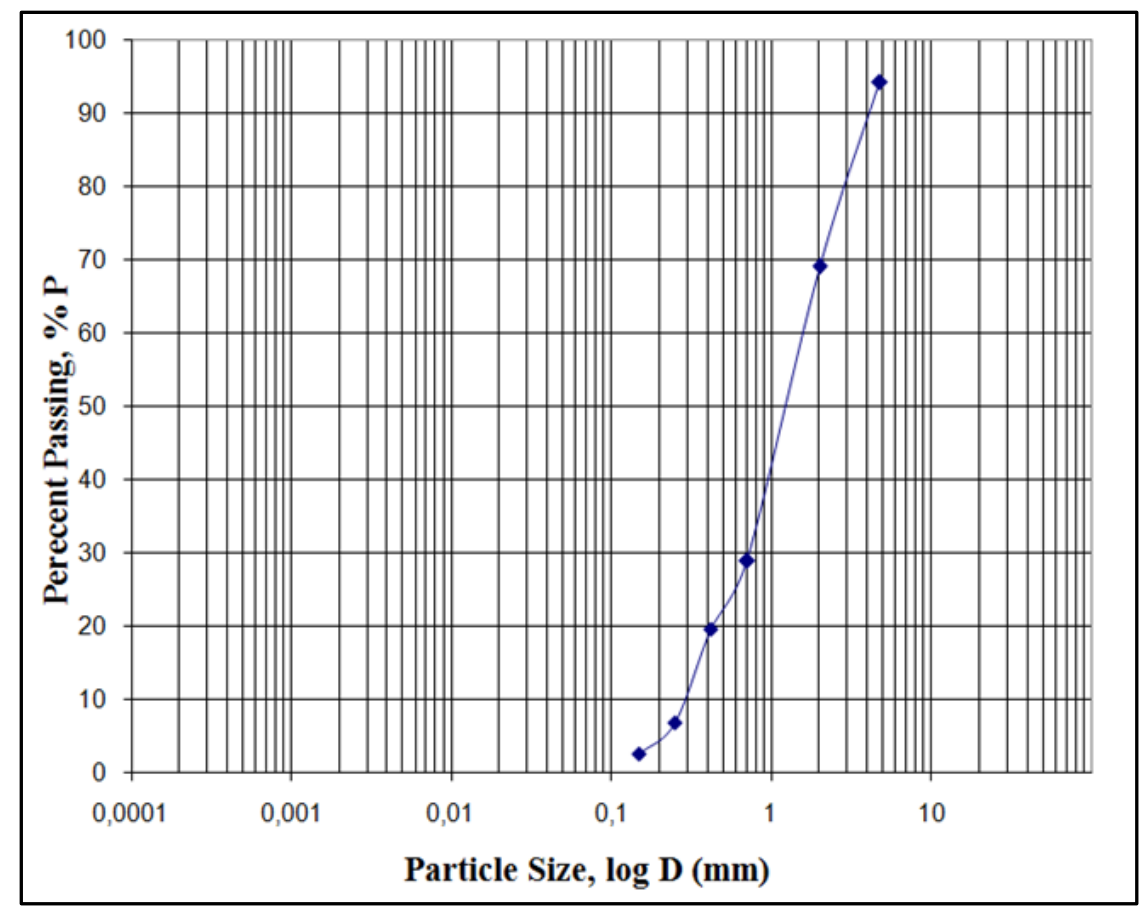

Fig.4 Sand for tests and particle size distribution curve

The geotechnical properties of the sand used in tests are given in Table 1. The dry unit weight of the sand was calculated with help of the following equation for the relative densities of $\mathrm{D}_{\mathrm{r}}=0.30$ and 0.70 . The internal friction angles of the sand for the relative densities were obtained by shear box test.

$\mathrm{D}_{\mathrm{r}}=\frac{\gamma_{\mathrm{dmax}}}{\gamma_{\mathrm{d}}}\left(\frac{\gamma_{\mathrm{d}}-\gamma_{\mathrm{d} \text { min }}}{\gamma_{\mathrm{d} \text { max }}-\gamma_{\mathrm{d} \text { min }}}\right)$ 
Table 1 Geotechnical properties of the sand

\begin{tabular}{|c|c|c|}
\hline Property & Unit & Value \\
\hline Grain specific gravity, $G_{s}$ & - & 2.64 \\
\hline Maximum dry density, $\rho_{d \max }$ & $\mathrm{Mg} / \mathrm{m}^{3}$ & 1.89 \\
\hline Minimum dry density, $\rho_{d \min }$ & $\mathrm{Mg} / \mathrm{m}^{3}$ & 1.58 \\
\hline Effective diameter, $\mathrm{D}_{10}$ & $\mathrm{~mm}$ & 0.28 \\
\hline $\mathrm{D}_{30}$ & $\mathrm{~mm}$ & 0.73 \\
\hline $\mathrm{D}_{60}$ & $\mathrm{~mm}$ & 1.71 \\
\hline Coefficient of uniformity, $\mathrm{C}_{\mathrm{u}}$ & - & 6.11 \\
\hline Coefficient of curvature, $\mathrm{C}_{\mathrm{c}}$ & - & 1.10 \\
\hline Internal friction angle, $\phi\left(\mathrm{D}_{\mathrm{r}}=0.70\right) \quad$ ASTM D3080M-11, (2011) & Degrees & 44.00 \\
\hline Internal friction angle, $\phi\left(\mathrm{D}_{\mathrm{r}}=0.30\right) \quad$ ASTM D3080M-11, (2011) & Degrees & 37.00 \\
\hline
\end{tabular}

\subsubsection{Loading Setup and Data Collection Tools}

The press of triaxial test equipment was used for application of the vertical load during the tests. The press is capable of loading at various speeds $(0.50 \mathrm{~mm} / \mathrm{min}-1.50 \mathrm{~mm} / \mathrm{min})$ thanks to the electric motor and was mounted on the steel frame fixed to the test tank for the vertical loading (Fig. 5(a)). A $50 \mathrm{kN}$ load cell was mounted vertically at the end of the press to measure applied loads. The load cell was calibrated before the tests. The vertically mounted loading head with a sharp end was used to load the model raft foundation. Time dependent applied loads were measured precisely with the help of the load cell. Fig. 5(b) shows the LS$5 \mathrm{~T}$ model load cell with a capacity of $50 \mathrm{kN}$ manufactured by CAS Corporation. The displacement transducers (Linear Variable Differential Transformers, LVDT) manufactured by OPKON which can measure displacements up to $150 \mathrm{~mm}$, were used to measure the settlement of the model foundation due to the vertical loading (Fig. 5(c)). The settlements were measured at two different points that were equal distance to the center of the model foundation. The settlement of the modelling was determined as the average of the two measurements. 


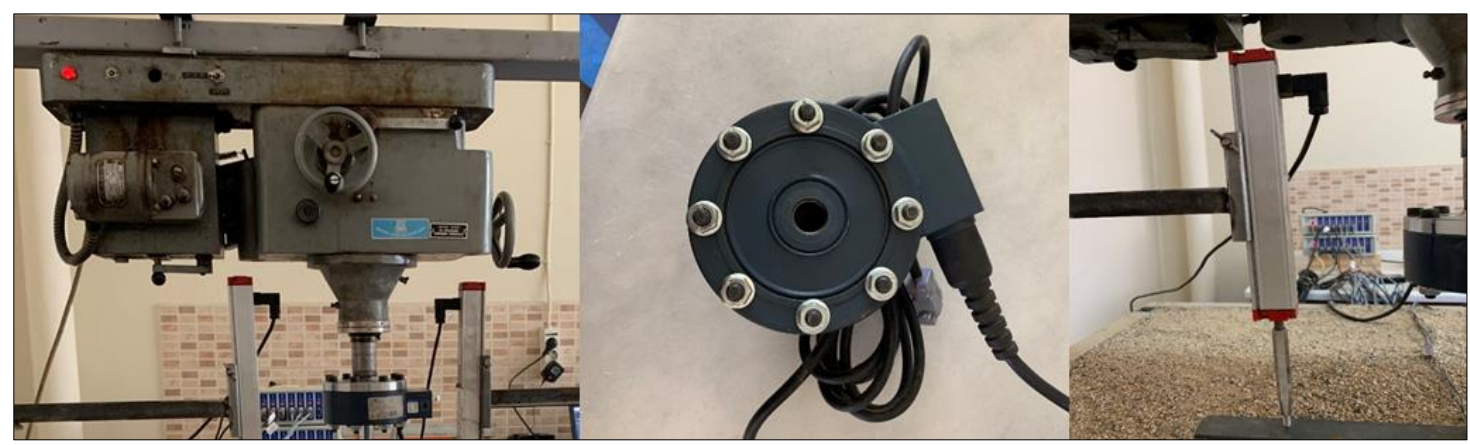

Fig. 5 Loading assembly a) load press, b) load cell, c) LVDT

During the experiments, the quantities measured by the load cell and the LVDTs were transferred to the computer with the aid of TDG branded data logger of Ai8b model with 8 channels input and RS-485 model gateway of the same brand (Fig. 6 (a)). These data were converted to numerical values with the help of CoDA Locomotive program (Fig. 6 (b) and (c)).

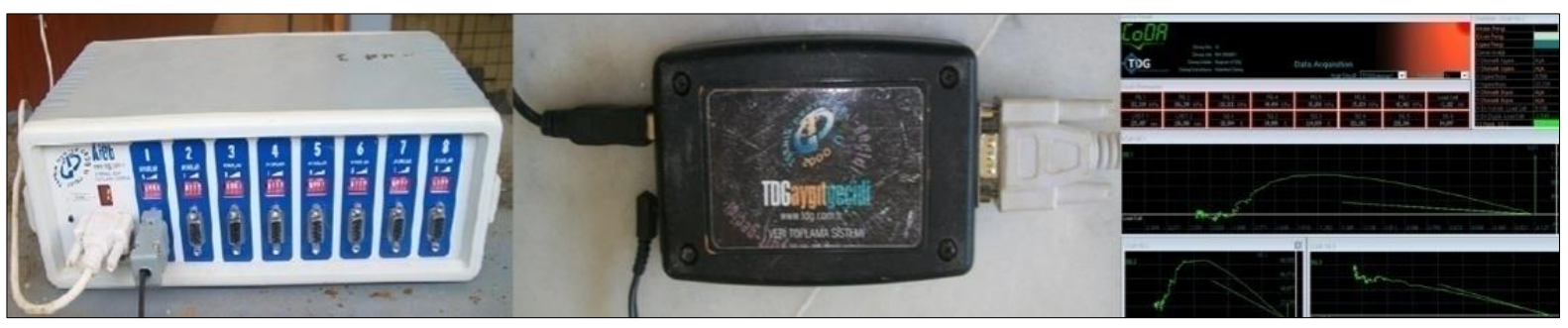

Fig.6 The data collection units a) the data logger, b) the gateway, c) the CoDA locomotive software

\subsubsection{A Typical Test}

The sand was placed and compacted in the test tank in layers. For $30 \%$ relative density $\left(\rho_{d}\right.$ $=1.66 \mathrm{Mg} / \mathrm{m}^{3}$ ), the sand required for $50 \mathrm{~mm}$ layer was poured into the test tank at a close distance to prevent compacting, the surface of the sand was made horizontal with a water balance, and thus the sand was homogeneously placed. The sand layer was compacted with a vibration device in the case of $70 \%$ relative density $\left(\rho_{d}=1.79 \mathrm{Mg} / \mathrm{m}^{3}\right)$. The height of the sand layer was controlled by the horizontal lines indicating the layer thickness on the internal surfaces of the tank (Fig. 7). 


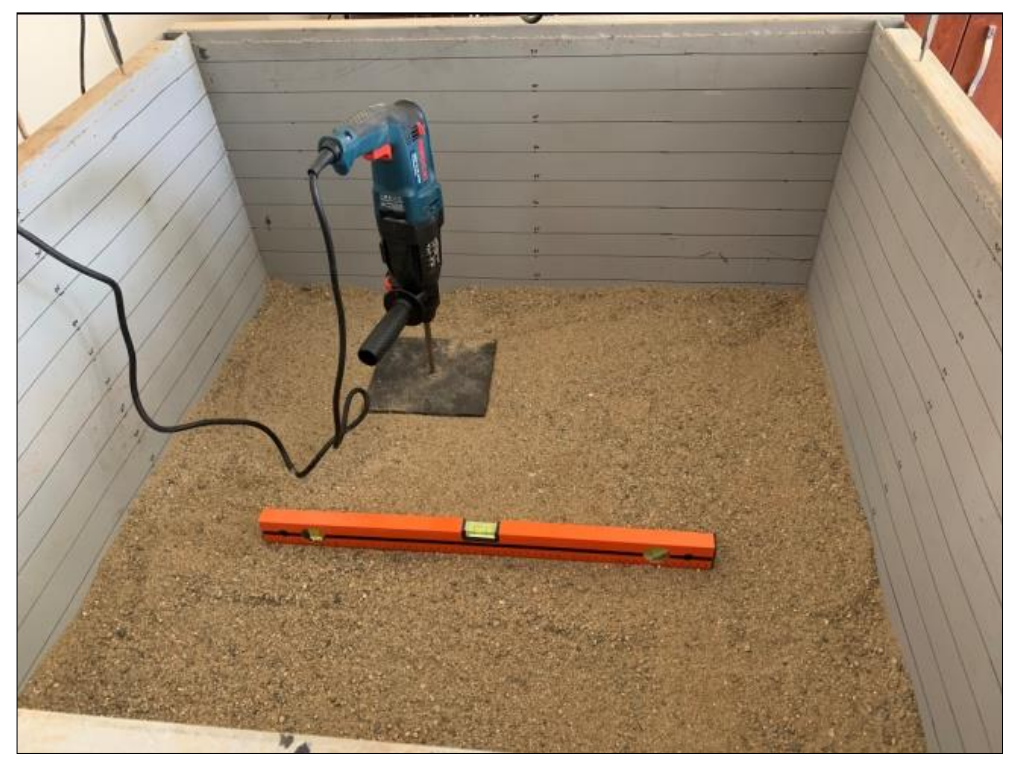

Fig. 7 The placement of the sand for a typical test

After placement of the sand into the tank, the model raft foundation was inserted into the sand at a constant penetration rate of $0.50 \mathrm{~mm} / \mathrm{min}$. While the model raft foundation was inserting into the sand, its verticality was checked with water balance. Before starting the test, all measurement devices were placed in the experimental setup. The measurement devices consist of LVDT's placed on both sides of the loading head, the load cell mounted to the load press (Fig. 8). The initial values of the measurement devices are reset to zero and the load is applied vertically and very slowly. A constant loading speed of $0.50 \mathrm{~mm} / \mathrm{min}$ was applied until the desired settlement was achieved. If the bearing capacity cannot be determined completely from the determined load-settlement curves, some methods (0.1B method, Briaud and Jeanjean 1994, ( $\mathrm{B}=$ width of raft); Tangential intercept method, Trautmann and Kulhawy 1998; Log-Log method, Debeer 1970; and Hyperbolic method) can be used in geotechnical engineering to determine the bearing capacity. Different bearing capacity values can be obtained in each of these methods. Therefore, a single method should be determined when determining the value of bearing capacity. In this study, since no significant bearing capacity can be obtained from the vertical load-settlement curves, the $0.1 \mathrm{~B}$ method, which gives more practical values compared to other methods, is used. The data were recorded during the experiments with the help of the data logger and the gateway and they were converted to numerical values with the help of CoDA Locomotive program. With the help of experimental data, vertical load-settlement curves were drawn. In addition, the homogeneity of the compacted soil was checked with the specimen containers placed in the test tank after the test was completed. The tests were repeated three times for each relative density of soil, and the results were recorded. Then, it was seen that these results were compatible with each other for each condition. Therefore, the average curves of all three experimental measurements were shown in the Figures. 


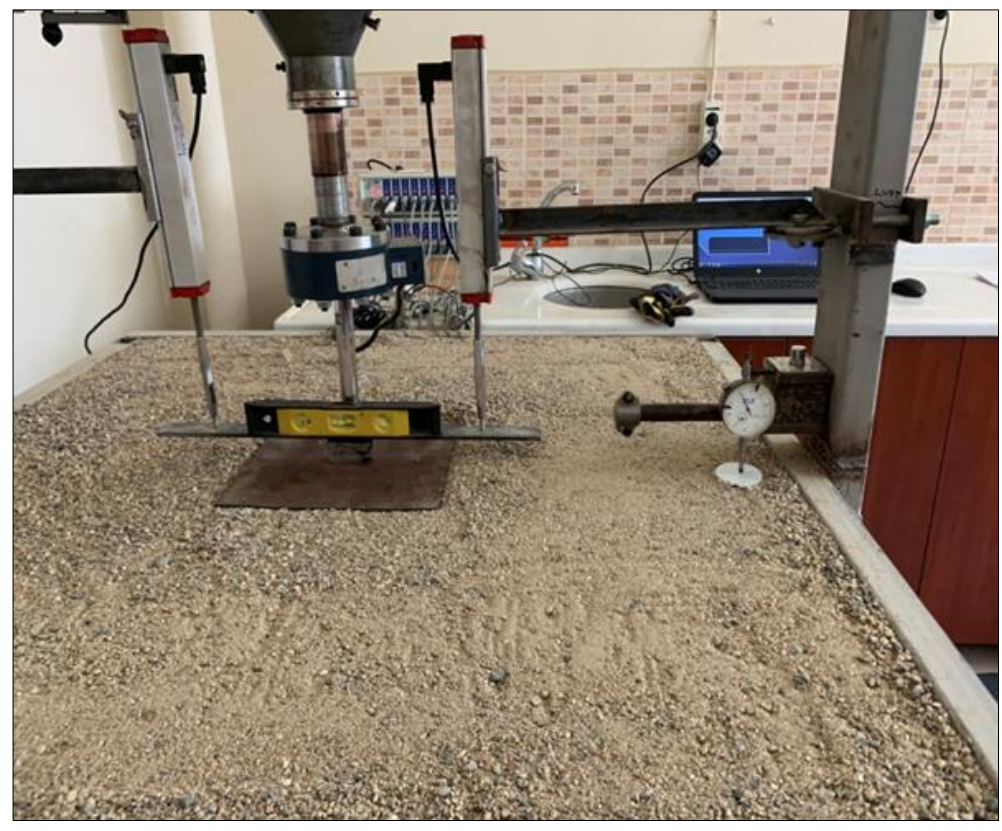

Fig. 8 The starting of the loading for a typical test

\subsubsection{Test program}

In order to determine the load-settlement behaviour of the model footing, the tests specified in Table 2 were carried out on the model footing resting on the sand with the different relative densities of $\mathrm{D}_{\mathrm{r}}=30 \%$ and $\mathrm{D}_{\mathrm{r}}=70 \%$.

Table 2 Test program for the load-settlement curves

\begin{tabular}{|c|c|c|c|}
\hline $\begin{array}{c}\text { Test } \\
\text { No }\end{array}$ & Model Foundation & $\begin{array}{c}\text { Relative } \\
\text { Density }\left(\mathbf{D}_{\mathbf{r}}\right)\end{array}$ & $\begin{array}{c}\text { Width of } \\
\text { Raft }(\mathbf{B}, \mathbf{m m})\end{array}$ \\
\hline $\mathrm{T}_{1,2,3}$ & Model Footing & $\% 30$ & 160 \\
\hline $\mathrm{T}_{4,5,6}$ & Model Footing & $\% 70$ & 160 \\
\hline
\end{tabular}

\subsection{Numerical Simulation}

Three-dimensional finite element analyses were performed to compare the model test results and to examine the load-settlement of the model footing in the sand. The numerical simulation was performed by using the ABAQUS/CAE v.6.13 package program, which is based on the finite element method. The test tank, the loading conditions, the model footing and the material properties were taken into account with the ABAQUS computer program (Fig. 9). 


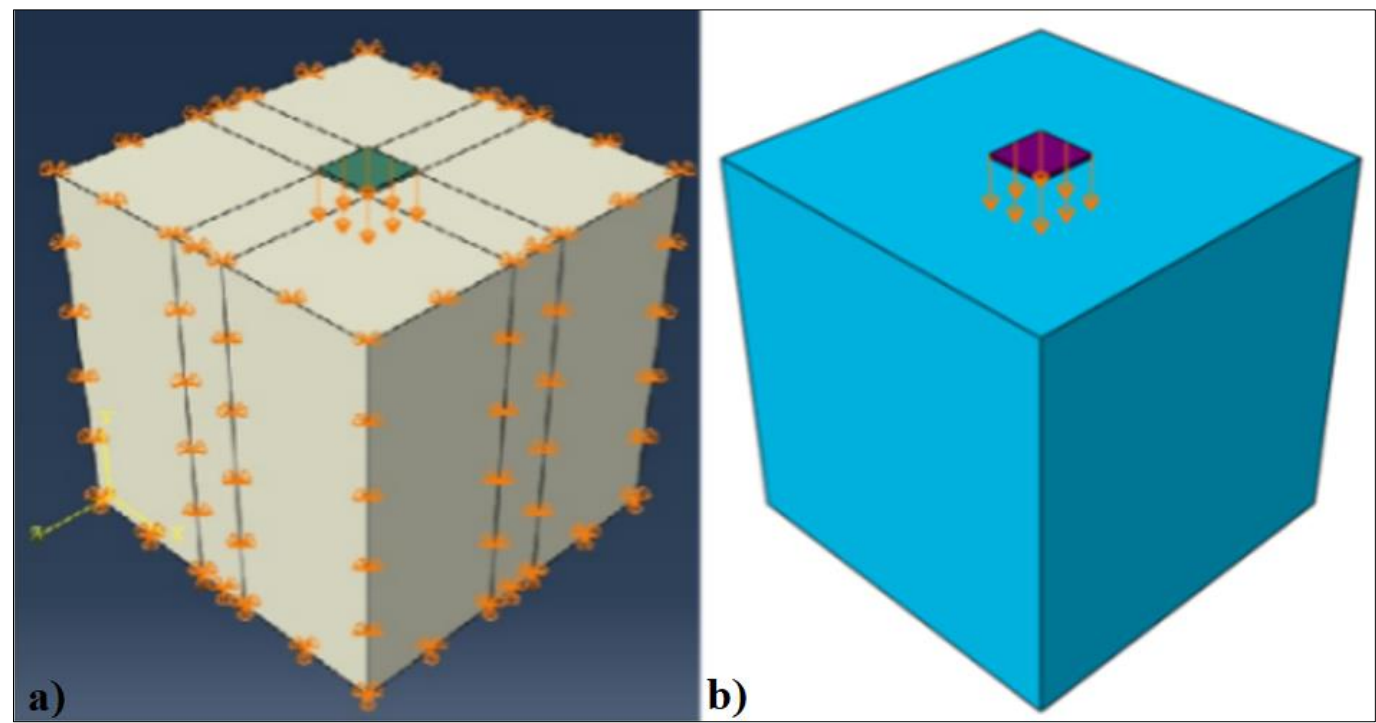

Fig. 9 Numerical analysis a) boundary condition, b) loading

While the elastic models are used in modelling the elastic behavior of the soil with ABAQUS finite element program, in modeling of the plastic behavior, plastic models such as MohrCoulomb Model, Modified Drucker-Prager Model, Bidirectional Flowing and Drucker-Prager Plasticity, Modified Glass-Clay Model, Modified Cap Model, Numerical Application (Implementation) can be used. Mohr-Coulomb (MC) model was used to reflect the soil properties and the experimental conditions in the three dimensional analysis made within the scope of the study. Mohr-Coulomb model includes five different parameters: modulus of elasticity (E), poisson's ratio (v), cohesion (c), internal friction angle $(\varnothing)$ and dilatation angle $(\psi)$. In the numerical analysis of the model raft foundations under the vertical load; loadsettlement curves are examined. In ABAQUS, the most suitable 3-dimensional continuous solid (C3D8R) element type has been selected to give the said results. The element type C3D8R has 8 nodes in the corners. In finite element modeling, stiffness matrix is written for each node and the solution is provided. However, the stiffness matrix written for each joint causes a waste of time during the solution. Therefore, the eight nodes that make up the element have been reduced to 1 integration point located at the midpoint of the element by the management of the reduced integration point. The Mohr-Coulomb (MC) model was used to simulate the sand properties. 3-D continuous solid (C3D8R) element type was selected for three-dimensional modeling. The Poisson's ratios (v) of the sand with the different relative densities were determined by Dutta and Saride (2015) and the dilatancy angles ( $\psi$ ) were found with the equation given by Schanz and Vermeer (1996). The material model parameters used in numerical analysis are given in Table 3. In addition, the properties of the model footing used in numerical analysis are given in Table 4. 
Table 3 The soil properties for the numerical analysis

\begin{tabular}{|l|c|c|}
\hline \multicolumn{1}{|c|}{ Parameters } & Unit & Value \\
\hline Dry density, $\rho_{d}\left(D_{r}=\% 30\right)$ & $\mathrm{Mg} / \mathrm{m}^{3}$ & 1.66 \\
\hline Dry density, $\rho_{d}\left(D_{r}=\% 70\right)$ & $\mathrm{Mg} / \mathrm{m}^{3}$ & 1.79 \\
\hline Internal friction angle, $\phi\left(D_{r}=\% 30\right)$ & Degrees & 37.00 \\
\hline Internal friction angle, $\phi\left(D_{r}=\% 70\right)$ & Degrees & 44.00 \\
\hline Poisson's ratio, $v\left(D_{r}=\% 30\right)$ & - & 0.35 \\
\hline Poisson's ratio, $v\left(D_{r}=\% 70\right)$ & - & 0.30 \\
\hline Dilatancy angle, $\psi\left(D_{r}=\% 30\right)$ & Degrees & 4.86 \\
\hline Dilatancy angle, $\psi\left(D_{r}=\% 70\right)$ & Degrees & 17.05 \\
\hline Elasticity modulus, E $\left(D_{r}=\% 30\right)$ & $\mathrm{kN} / \mathrm{m}^{2}$ & 9226 \\
\hline Elasticity modulus, $\mathrm{E}\left(D_{r}=\% 70\right)$ & $\mathrm{kN} / \mathrm{m}^{2}$ & 17418 \\
\hline
\end{tabular}

Table 4 The properties of the model footing for numerical analysis

\begin{tabular}{|c|c|c|c|c|c|c|c|}
\hline Model & Material & $\begin{array}{c}\text { D, B } \\
(\mathbf{m m})\end{array}$ & $\begin{array}{c}\mathbf{L}, \mathbf{B} \\
(\mathbf{m m})\end{array}$ & $\begin{array}{c}\text { Material } \\
\text { Model }\end{array}$ & $\gamma\left(\mathbf{k N} / \mathbf{m}^{\mathbf{3}}\right)$ & $\begin{array}{c}\mathbf{E} \\
\left(\mathbf{k N} / \mathbf{m}^{\mathbf{2}}\right)\end{array}$ & $\mathbf{v}$ \\
\hline Raft & Steel & 160 & 160 & Linear Elastic & 78.5 & $2 \times 10^{8}$ & 0.300 \\
\hline
\end{tabular}

As mesh size (element size) decreases in finite element analysis, the convergence to the real result develops. However, when the mesh is very small, the duration of the analysis takes weeks. If mesh size increases, solution time is shortened but the analysis cannot be completed due to convergence error. As a result, optimum mesh size was determined by making some analyses with various mesh sizes. For this reason; Mesh size was selected as $10 * 20 \mathrm{~mm}$ in both directions along the width of the model raft foundation, while the mesh size was selected as $20 * 20 \mathrm{~mm}$ in the other sections. The mesh size of the model footing is basically $1 \mathrm{~mm}$ for finite element size. Figure 10 shows the finite element meshes of the model footing. 


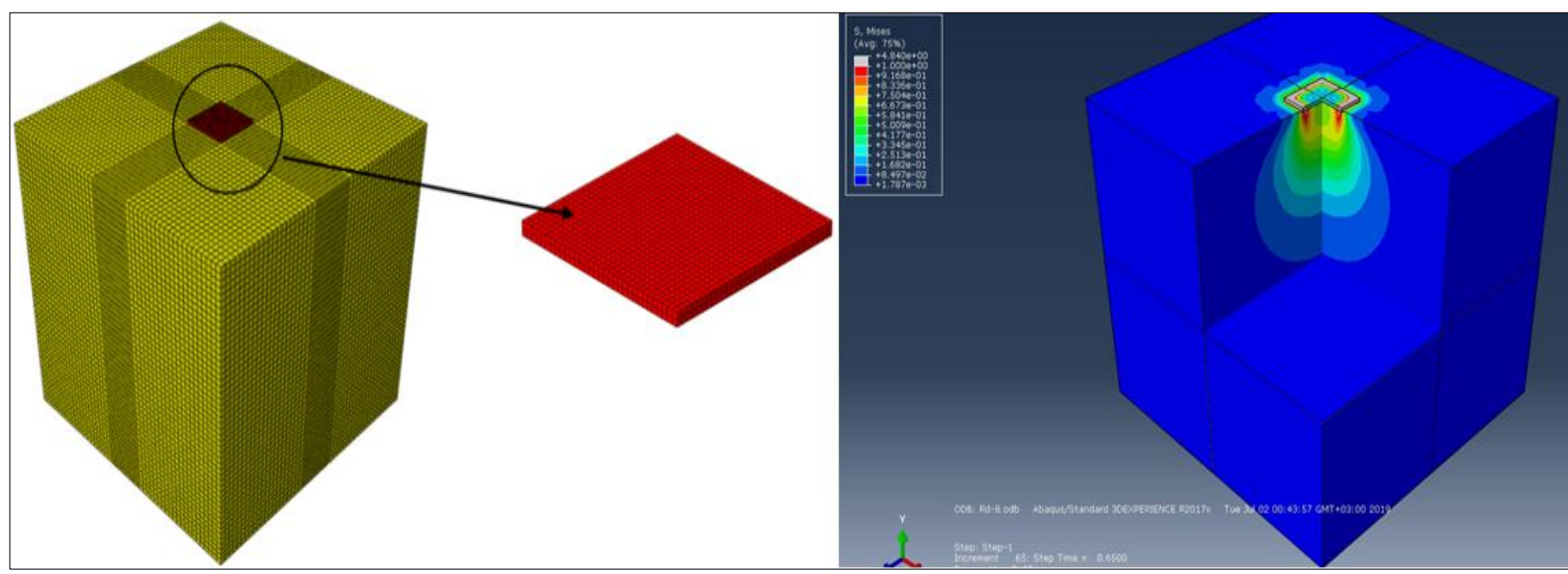

Fig.10 The finite elements for the model footing

The parameters and sequence of the numerical analyzes prepared for the determination of load-settlement behaviour in the model footing are given in Table 5. The experimental procedure in laboratory tests was conformed in numerical analysis.

Table 5 Numerical analysis program

\begin{tabular}{|c|c|c|c|}
\hline $\begin{array}{c}\text { Test } \\
\text { No }\end{array}$ & Model Foundation & $\begin{array}{c}\text { Relative } \\
\text { Density }\left(\mathbf{D}_{\mathbf{r}}\right)\end{array}$ & $\begin{array}{c}\text { Width of } \\
\text { Raft }(\mathbf{B}, \mathbf{m m})\end{array}$ \\
\hline $\mathrm{A}_{1}$ & Model Footing & $\% 30$ & 160 \\
\hline $\mathrm{A}_{2}$ & Model Footing & $\% 30$ & 160 \\
\hline $\mathrm{A}_{3}$ & Model Footing & $\% 70$ & 160 \\
\hline $\mathrm{A}_{4}$ & Model Footing & $\% 70$ & 160 \\
\hline
\end{tabular}

\section{Results and Discussions}

In this section, the results of the small-scale model tests and finite element analysis related to the parameters which can be effective on load-settlement behaviour of the model footing which are placed in the sand under the effect of vertical load are presented and examined. Studies have focused on the determination of the load-settlement behaviour of the model raft foundation. The raft foundations are loaded on the sand with the different relative densities. The load-settlement curves of the raft foundation were obtained. Figure 11 shows the loadsettlement curves obtained for the raft in case of $\mathrm{D}_{\mathrm{r}}=30 \%$ and $\mathrm{B}=160 \mathrm{~mm}$. The results of the numerical model were compared with the experimental results in order to evaluate to what extent they were successful in reflecting behavior of the model footing. Since Mohr-Coulomb material model has a linear load-displacement relationship up to the yield state, a close-tolinear load-settlement relationship was determined for the model footing in the numerical model. The load-settlement relationship was markedly non-linear in tests. In other words, an increased rigidity was observed in low load ranges but, decrease of rigidity was observed in great load ranges. The bearing capacity of the soil determined experimentally increases with the relative density and this increasement are in agreement with the numerical simulation for the low relative density. 


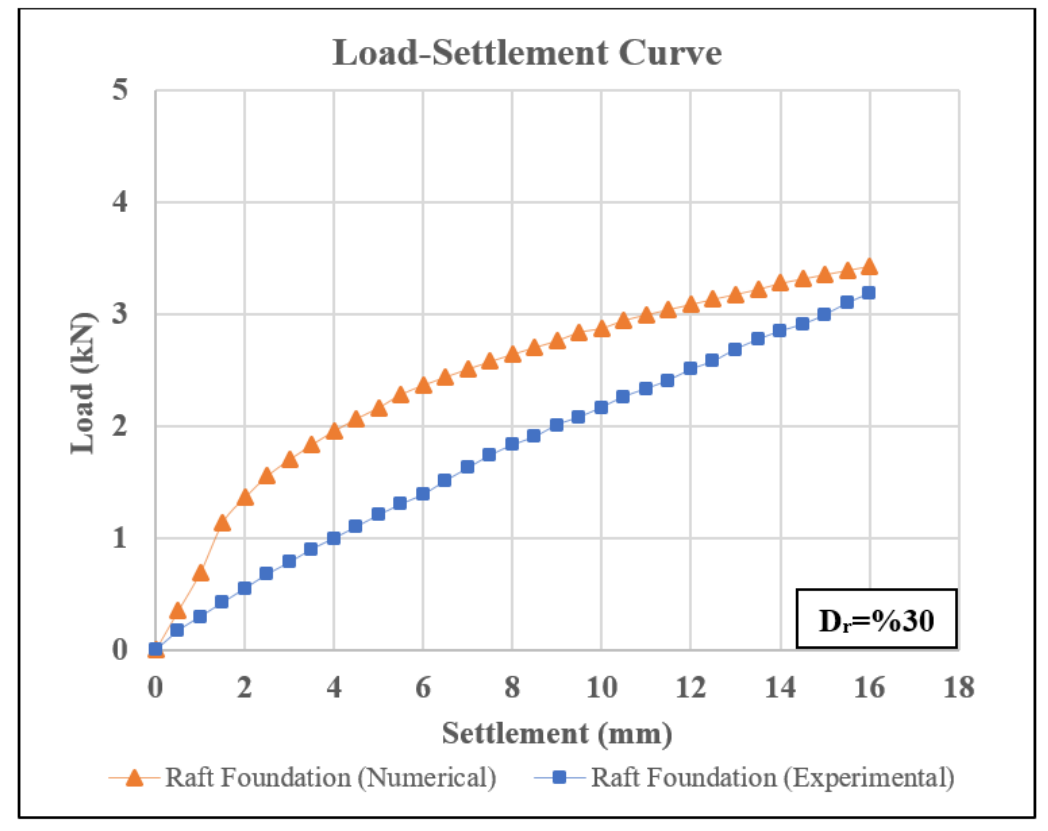

Fig.11 The load-settlement curves for $\mathrm{D}_{\mathrm{r}}=\% 30$

Figure 12 shows the load-settlement curves obtained for the piled raft in case of $\mathrm{D}_{\mathrm{r}}=70 \%$ and $\mathrm{B}=160 \mathrm{~mm}$. The results of the numerical model were compared with the experimental results in order to evaluate to what extent they were successful in reflecting behavior of the model footing. A close to linear load-settlement relationship was determined for the model footing in the numerical model because the Mohr-Coulomb material model has a linear loaddisplacement relationship up to the yield state. The load-settlement relationship was markedly non-linear in tests. This is all to say, an increased rigidity was observed in low load ranges but, decrease of rigidity was observed in great load ranges. The bearing capacity of the soil determined experimentally increases with the relative density and this increasement are in agreement with the numerical simulation for the high relative density.

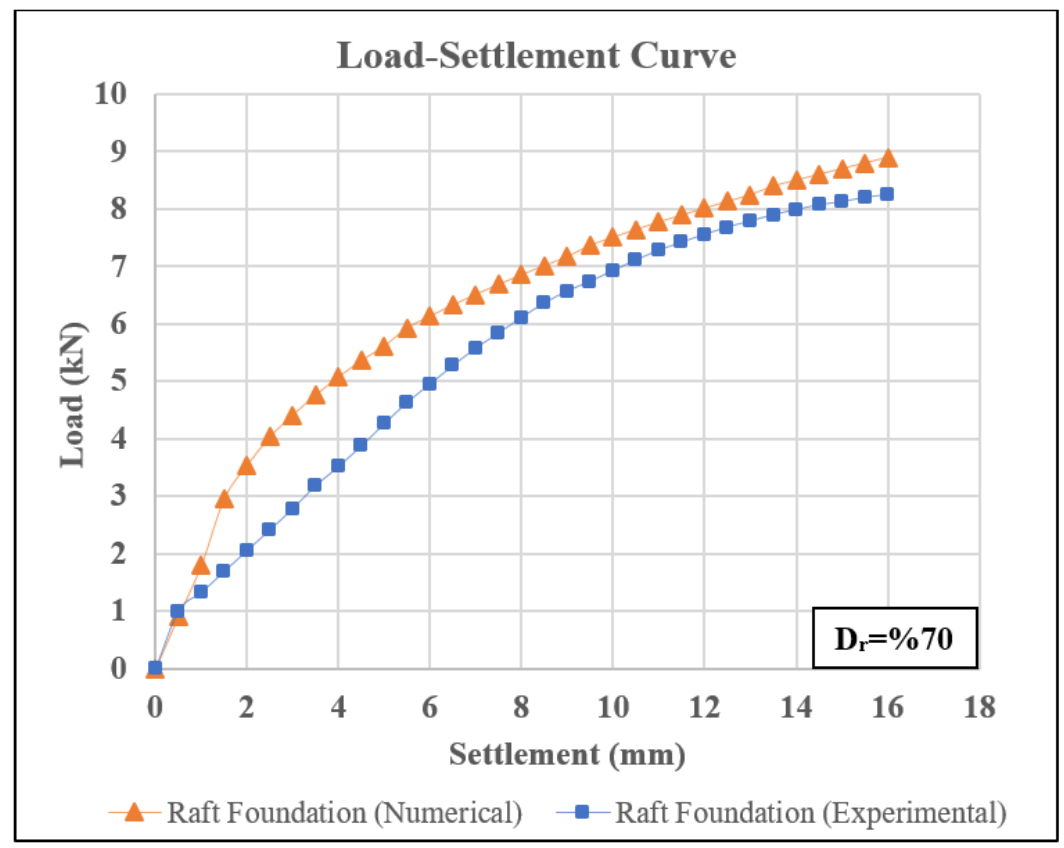

Fig. 12 The load-settlement curves for $\mathrm{D}_{\mathrm{r}}=\% 70$ 
Numerical analyses were performed in ABAQUS program for the model footings which were found in the sand having the different relative density. The vertical settlement obtained by the numerical analysis for the model footings are shown in Fig. 13.

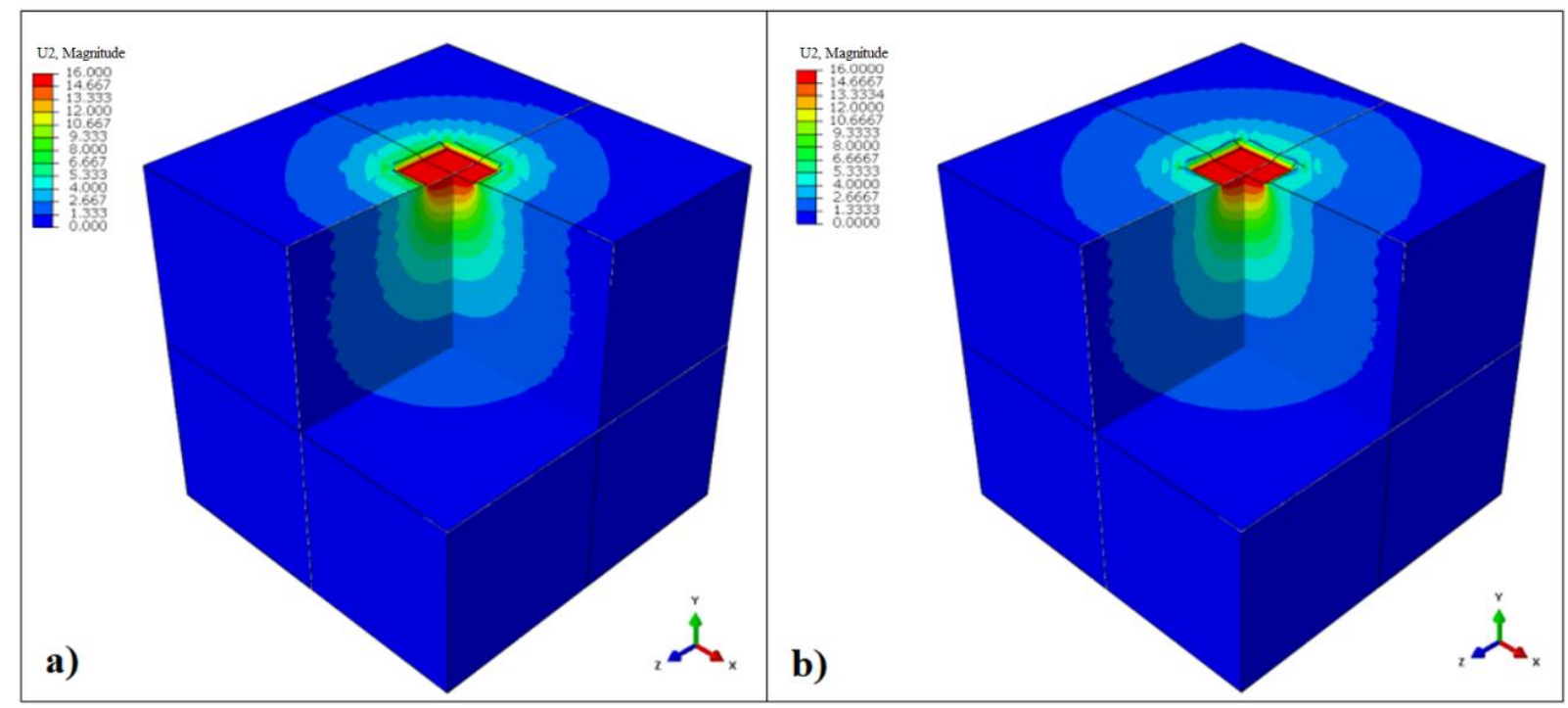

Fig. 13 The vertical settlements obtained by the numerical analysis of the model footing a) $\mathrm{D}_{\mathrm{r}}=\% 30$, b) $\mathrm{D}_{\mathrm{r}}=\% 70$

As a result of the tests carried out for the determination the load-settlement behaviour and bearing capacity of the model footing, it was observed that relative density is significant a parameter in terms of bearing capacity of the raft. The load-settlement curves, which are measured in the experimental studies and determined from the numerical simulation, are in agreement and the difference between them is around $8 \%$. Relative density was observed to have an effect on bearing capacity of $159 \%$. The bearing capacity of the soil determined experimentally increases with the relative density and this increasement are in agreement with the numerical simulation for both low relative density (30\%) and high relative density $(70 \%)$ (Fig. 14). 


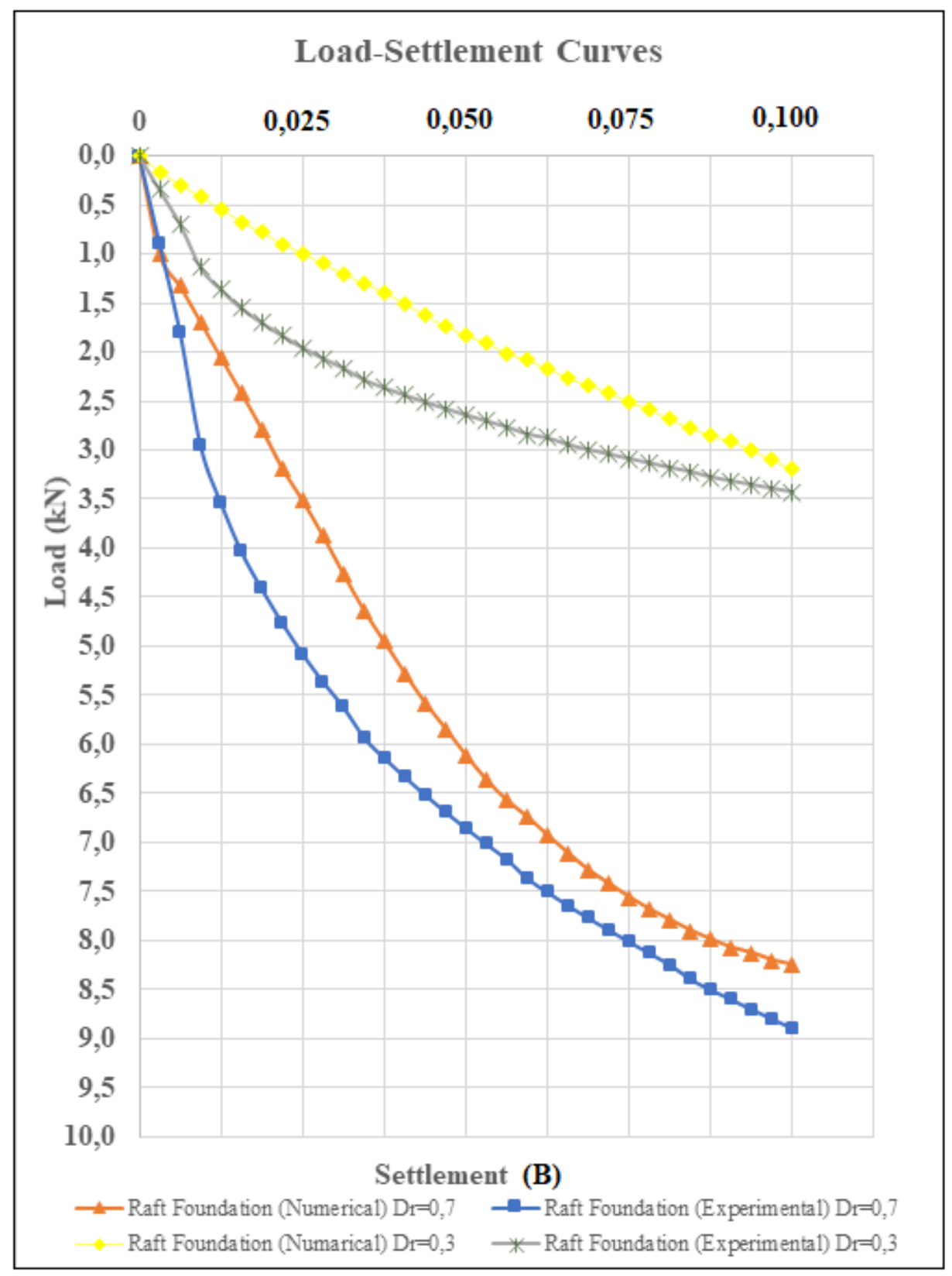

Fig. 14 The load-settlement curves obtained by the numerical analysis and $1 \mathrm{~g}$ physical model tests

\section{Conclusion}

In the present study, it is aimed to determinate the bearing and load-settlement behavior of the shallow foundations. For this purpose, a test setup has been formed and loading tests have been carried out by means of small scale model foundation rest on the granular soil with the different relative densities situations. A numerical model of the experimental setup was created in the ABAQUS (finite element software) and some simulations were performed for certain loading tests. The main results obtained from the experimental and numerical studies are as follows: 
- The difference between the bearing capacities of the model footing obtained from numerical analysis and experimental studies was about $8 \%$. That is to say, the shallow foundation system can be simulated with sufficient accuracy by the three-dimensional finite element method in which the sand is modeled with the Mohr-Coulomb material model.

- It is determined from the load-settlement curve that as the relative density increasing from $\mathrm{D}_{\mathrm{r}}=0.3$ to $\mathrm{D}_{\mathrm{r}}=0.7$, the rigidity of the model footing increases depending on the relative density.

As the relative density increasing from $\mathrm{D}_{\mathrm{r}}=0.3$ to $\mathrm{D}_{\mathrm{r}}=0.7$, the bearing capacity of the model footing has increased by $154-167 \%$.

\section{Notation}

B : Width of model raft foundation

$\mathrm{C}_{\mathrm{c}} \quad$ : Curvature coefficient

$\mathrm{C}_{\mathrm{u}} \quad$ : Uniformity coefficient

$\mathrm{D}_{\mathrm{r}} \quad$ : Relative density

$\mathrm{D}_{10} \quad$ : Effective diameter

e : Void ratio

E : Elasticity modulus

$\mathrm{G}_{\mathrm{s}} \quad$ : Grain specific gravity

$\mathrm{q}_{\mathrm{s} \text { snr }} \quad$ : Ultimate bearing capacity

LVDT : Linear Variable Differential Transformers

SW : Well graded sand

$Q_{R} \quad$ : Bearing capacity of raft

$\phi \quad$ : Internal friction angle

$\rho \quad$ : Unit weight

v : Poisson ratio

$\psi \quad$ : Dilatancy angle

\section{References}

ASTM D-854. 2006. "Standard test methods for specific gravity of soil solids by water pycnometer", ASTM International, West Conshohocken. 
ASTM D3080M-11. 2011. "Standard test method for direct shear test of soils under consolidated drained conditions", ASTM International, West Conshohocken.

ASTM D4253-16. 2016. "Standard test methods for maximum index density and unit weight of soils using a vibratory table", ASTM International, West Conshohocken.

ASTM D-6913. 2017. "Standard test methods for particle-size distribution (gradation) of soils using sieve analysis", ASTM International, West Conshohocken.

Briaud, J. L. and Jeanjean, P. 1994. "Load settlement curve method for spread footings on sand. Vertical and horizontal deformations of foundations and embankments", ASCE, 2, 17741804.

Broms, B. B. 1963. "The effect of degree of saturation on the bearing capacity of flexible pavements", Highway Research Record, 71, 1-14.

Cao, X.D., Wong. I.H. and Chang, M.F. 2004. "Behavior of Model Rafts Resting on PileReinforced Sand", Journal of Geotechnical and Geoenvironmental Engineering, 130(2):129138.

Costa, Y. D., Cintra, J. C. and Zornberg, J. G. 2003. "Influence of matric suction on the results of plate load tests performed on a lateritic soil deposit", Geotech. Testing J., 26(2), 219-226.

Debeer, E. E. 1970. "Experimental determination of the shape factors and the bearing capacity factors of sand”, Geotechnique, 20(4), 387-411.

Dutte, T. T. and Saride, S. 2015. "Effect of confining pressure, relative density and shear strain on the poisson's ratio of clean sand", 50th Indian Geotechnical Conference.

Hosseini, A. 2014. "Effect of confinement pressure on bearing capacity of two samples of square and strip footing”, Springer Plus, 3 (1), 1-5.

Hossein, R., Nazir, R. and Momeni, E. 2016. "Bearing capacity of thin-walled shallow foundations: an experimental and artificial intelligence-based study", Journal of Zhejiang University-SCIENCE A (Applied Physics \& Engineering), 17 (4), 273-285.

Krabbenhoft, S., Clausen, J. and Damkilde, L. 2012. "The bearing capacity of circular footings in sand: comparison between model tests and numerical simulations based on a nonlinear Mohr failure envelope", Advances in Civil Engineering, 1-10.

Mendonça, A.V. and Paiva, J.B. 2000. "A boundary Element Method for the Static Analysis of Raft Foundations on Piles", Engineering Analysis with Boundary Elements, 24(3):237-247. doi:10.1016/S0955- 7997(00)00002-3

Meyerhof, G. G. 1951. "The ultimate bearing capacity of foundations", Géotechnique, 1951, (2), 301-332. 
Mohamed, F. M. O. and Vanapalli, S. K. 2006. "Laboratory investigations for the measurement of the bearing capacity of an unsaturated coarse-grained soil", Proceedings of the 59th Canadian Geotech. Conf., Vancouver, B.C, 219-226.

Nguyen, D. D. C., Jo, S. B. and Kim, D. S. 2013. Design method of piled-raft foundations under vertical load considering interaction effects. Computers and Geotechnics, 47, 16-27.

Oh, W. T. and Vanapalli, S. K. 2001. "Modeling the stress versus settlement behavior of model footings in saturated and unsaturated sandy soils," Canadian Geotech. J., 48, 425-438.

Oloo, S. Y., Fredlund, D. G. and Gan, J. K. M. 1997. "Bearing capacity of unpaved roads", Canadian Geotech. J., 34, 398-407.

Schanz, T. and Veermer, P. A. 1996. "Angles of friction and dilatancy of sand", Geotechnique, 46, 1, 145-151.

Terzaghi, K. (1943) “Theoretical Soil Mechanics”, John Wiley and Sons, New York, USA.

Trautmann, C. H. and Kulhawy, F. H. 1998. "Uplift load-displacement behavior of spread foundations", Journal of Geotechnical Engineering, 114, 2, 168-183.

Vanapalli, S. K. and Mohamed, F. M. O. 2007. "Bearing capacity of model footings in unsaturated soils", Springer Proc. in Physics. Springer, 112, 483-493.

Vanapalli, S. K. and Mohamed, F. M. O. 2013. "Bearing capacity and settlement of footings in unsaturated sands", International Journal of GEOMAT, 5 (1), pp. 595-604. 